\title{
Legal pluralism and stigma: a case-study of customary resurgence in the Chakma communities of Bangladesh and India
}

\author{
Margaret O’Brien* \\ Warwick Law School, University of Warwick, Coventry, UK \\ *Corresponding author. E-mail: Maggie.O-Brien@warwick.ac.uk
}

\begin{abstract}
This paper explores the complex iteration of ethnic identity and legal culture amongst the Chakma peoples of the Chittagong Hill Tracts of Bangladesh and the hill territories of Tripura, India. Its hypothesis is that the stigma of tribal identity is more likely to be sustained in situations of 'weak' pluralism - that is, where the customary system is formally annexed to the state. However, such stigma is more likely to be dispelled where numerous, competing legal jurisdictions collide in a 'strong' pluralism expressed as a relatively autonomous legal domain, overlapping legal jurisdictions and in the presence of a productive and potentially creative 'interlegality'. Conversely, strong state recognition of identities, such as can be found in India, appears to be linked to weak local pluralism, creating an insular and inward-looking community that embraces stigma and the preservation and use of customary practices. In conclusion, this paper asserts that formal state recognition in a situation of legal pluralism tends to freeze identities in a facsimile of the colonial trope of tribe, whilst conflict between the communities and the state generates new and resistant identities and new iterations of customary law.
\end{abstract}

Keywords: legal pluralism; tribes; Adivasi; stigma

\section{Introduction}

The concept of 'tribe' first surfaced in South Asia to describe, pejoratively, the diverse mountain-dwelling peoples of the Zomia mountains at the north-eastern borderlands of British India (Beteille, 1986; Hunter, 1876). Tribe was an overarching category that conjured ideations of 'wildness' and 'innocence', identifying the hill peoples as objects of justified domination (Skaria, 2001; Chandra, 2013). Their primitivism was presumed to require special protections from foreign influence, and this presumption materialised in a separate and distinctive form of indirect rule that explicitly divided the citizenry by geographies and law (Mantena, 2010). Mountain territories in the north-east were spatially demarcated from plain-land India, and then further divided by internal borders or 'inner lines', into separate Hill Tracts governed by indigenous institutions explicitly co-opted to regulate tribal communities on behalf of the colonial state (Baruah, 2005). Tribal identity was at once inherently stigmatised as 'backwards' and intricately connected to notions of a differential citizenship institutionalised through and mirrored by law (Mamdani, 2012).

The legacy of the colonial rule has indelibly marked the Chakma to this day; they are still exceptional in their mountain geography and diverse demographic profile, and still demarcated from majority populations by constitutional and legal institutions that directly and indirectly underscore differential concepts of citizenship for the former tribes (Chandra, 2013). Law and identity remain

(C) The Author(s), 2021. Published by Cambridge University Press. This is an Open Access article, distributed under the terms of the Creative Commons Attribution licence (http://creativecommons.org/licenses/by/4.0/), which permits unrestricted re-use, distribution, and reproduction in any medium, provided the original work is properly cited. 
closely entwined through a continued reliance on customary legal systems to regulate minority communities, creating a legal hierarchy akin to the 'classical' legal pluralism associated with the tiered legal systems of the Global South (Engle Merry, 1988). Beyond these superficial similarities, the lifeworlds of the former colonial tribes have followed multiple and disparate trajectories, bifurcated by partition and the radically different constitutional and political approaches to cultural diversity adopted in the postcolonial states of Bangladesh and India, and then, on a more granular and hyperlocal level, fragmented by a huge diversity of demographic and political constellations within nation-state borders. To understand the Chakma, therefore, one must study the intricate connections between law and identity, and the diversity of tribal experience in the present-day Hill Tracts, to identify what factors are most likely to perpetuate or extinguish the historical stigma of tribal belonging.

This paper explores the legacies of the particular strategy of indirect rule imposed by the 'Inner Lines' of the north-eastern territories of colonial India. These internal borders determined all hill dwellers as 'tribes', effected their spatial confinement to limited hill territories and introduced an enduring link between law, ethnic identity and stigma in one deft political move. The paper draws on research in two Chakma communities - one in the Rangamati district of Bangladesh and the other in the Kanchanpur valley in India - to explore how tribal stigma manifests and is utilised when legal pluralism sustains the close but highly problematic relationship of law, ethnic identity and state power in the Hill Tracts. Analysis of the perceptions of Chakma customary leaders on both sides of the borders suggests that the way in which a community situates itself in relation to the state and to other minority communities will affect both the inherence of stigma and the nature of customary legal practice. In Bangladesh, the messy post-conflict environment generates novel political identities in minority communities eager to assert their rights as equal citizens. On the other hand, in India, strong state recognition of 'tribal' identities and weak local pluralism lead to an insular and inward-looking approach to customary legal reform. The research presented in this paper establishes a link between the strength or diversity of pluralism inside the customary arena and the extent to which the stigma associated with the colonial attribution of 'tribe' has been reasserted or rejected in the post-colonial era.

In order to ground this argument that legal pluralism affects the reassertion or rejection of colonial-era stigmatised identities, the paper will first begin with a theoretical discussion on how stigma intersects with power and the difference between 'strong' and 'weak' legal pluralism. Next, a brief discussion on the historical context of the Chakma and a short note on the methods used to collect data for this study will be provided. The remainder of the paper will explore how the stigmatised tribal identity of the Chakma evolves in the post-colonial nations of Bangladesh, where weak state recognition and 'strong' legal pluralism promote the de-emphasis of the 'backwards' stigma, and in India, where strong state recognition and 'weak' legal pluralism lead to an inward-looking and stigma-retaining community.

In conclusion, the paper suggests that, in Bangladesh, where 'weak' recognition of legal identities and 'strong' legal pluralism prevail, tradition, diversifying communities, urbanisation and ideological differences all assert pressure on the Chakma identity and lead to a competition for recognition and political power in Bangladesh. In contrast, in countries like India, where strong legal identities are maintained and legal pluralism is weak, the Chakma seek refuge in, and assert, their stigmatised identity, look inward and fiercely protect their customary practices and beliefs. These two communities, their histories and responses to the state, will be discussed in turn.

\section{Stigma and legal pluralism}

The hypothesis advanced in this paper is twofold: the stigma of tribal identity is more likely to be sustained in situations of 'weak' pluralism - that is, where the customary system is formally annexed to the state. However, such stigma is more likely to be dispelled where numerous, competing legal jurisdictions collide in a 'strong' pluralism expressed as a relatively autonomous legal domain, overlapping legal jurisdictions, and in the presence of a productive and potentially creative 'interlegality'. 
In order to make this argument, the concept of 'stigma' must first be defined to illustrate its connection and reaction to the state of legal pluralism. This section aims to layout the fundamental features to both stigma and legal pluralism.

Erving Goffman conceptualises stigma as an attribute of social identity that is deeply discrediting, but one that must be articulated through the 'language of relationships'. Stigma occurs where any group of 'normal' people determine a pejorative attribute that marks an individual or community as different and inferior (Goffman, 1963). Stigmatised attributes can be physical characteristics, hidden blemishes of character or 'tribal stigma' derived from race, nation or religion, but however stigma manifests, it reduces a 'whole and usual person to a tainted, discounted one' (Goffman, 1963, p. 14). Subsequent refinements of Goffman's definition have addressed more explicitly the power relations that enable these processes, noting that 'Stigma involves labelling, stereotyping, separating, status loss, and discrimination co-occur in a power situation that allows these processes to unfold' (Link and Phelan, 2001, p. 382). The range of socially acceptable attributes is likely to be determined by the majority within any given social group. More recent research suggests that stigma can be reciprocal, regardless of the hierarchy of power: 'certain groups or individuals not only disavow dominant perspectives regarding stigma but also impose their own version of stigma on the dominant society' (Kusow, 2004, p. 194).

In the context of Chakma communities and their identity, the concept of stigma can be usefully applied to the designation of indigenous populations as political and legal subjects defined by inferiority. Second, understanding stigma as a process enabled by unequal power relations shifts understanding of stigma away from the ostensibly 'deviant' individual or group (Goffman) towards a structurally located definition that recognises stigma as a function of power (Link and Phelan, 2001). Third, acknowledging the agency of targeted groups or individuals suggests that the processes of stigmatisation can be reversed, so that the stigmatised object might not only reject the dominant perceptions of stigma, but develop and attribute pejorative markers to the dominant or stigmatising group (Kusow, 2004). Finally, given the dominant role of the state in framing community identities, it must follow that the processes of minority recognition will influence whether a community remains stigmatised in the eyes of the majority.

In colonial India, stigmatised identities were entrenched in the law, and therefore the legal and customary institutions discussed in this paper - that is, the courts, legislation and laws used by the Chakma - were linked to colonial legal pluralism. In Bangladesh, this took place through the grounding of customary law in colonial statutes and legislation, and in India through the constitutional framework of the Sixth Schedule of the Indian Constitution. Notwithstanding these enduring colonial legacies, legal pluralism as it plays out in practice needs to be thought of as a dynamic and constitutive process even in India's north-east, where the model of legal plurality since the colonial-era prima facie suggests a strict separation of state and community law (Guha, 1996). Legal anthropologist Sally Engle Merry provides a seminal definition of this model of 'classical' legal pluralism in which there exist 'different bodies of law for different groups of the population varying by ethnicity, religion, nationality, or geography and when the parallel legal regimes are all dependent on the state legal system' (Engle Merry, 1988, p. 871). In this conceptualisation, state and customary law are embedded in unequal power and customary institutions were subordinate despite providing 'spaces' for resistance.

Legal pluralism developed to describe situations in which different, competing rule sets or fields existed within the same jurisdiction to form overlapping, mutually reinforcing or even conflicting normative frameworks within one domain, becoming 'a descriptive theory (that) deals with the fact that within any given field, law of various provenance may be operative' (Griffiths, 1986, p. 39). This theoretical expansion introduced a scalar element to legal pluralism; classical legal pluralism was 'weak', as it involved the absorption and containment of law-making within the state so, for example, formal recognition of a customary system would weaken its autonomy and increase state dominance. A condition of 'strong' pluralism referred to different, competing rule sets or fields existing within the same jurisdiction, and encompassed 'bottom-up' rule-making and the possibility of law existing without formal rule sets and rationality. Santos further expanded the scope of legal pluralism by explicit reference to the potential for bottom-up law to generate resistance, exploring the possibility of law being 
developed in subaltern spaces, absent state control, and potentially drawing on multiple rule sets and concepts of law (Santos, 2002). His conception specifically referenced the globalisation of law, as evidenced by situations in which concepts such as human rights, resistance and indigeneity spilled over state borders to influence law-making at the level of community. He writes of the creative potential of multiple, overlapping sources of rule generation: 'The conception of different legal spaces, superimposed, interpenetrated and mixed in our minds as much as in our actions ... our legal life is constituted by the intersection of legal orders, that is by inter-legality' (Santos, 2002, p. 457).

Ideations of 'scale' advanced by Griffiths and 'interlegality' advanced by Santos both inform the analysis presented in this paper. Furthermore, legal pluralism as a constitutive process also aligns closely with Link and Phelan's understanding of stigmatisation as a process defined by power relations (Link and Phelan, 2001). In exploring how the intersection of political identities with the law is an iterative process between state and community, a hypothetical question emerges: What aspects of the dynamic processes involved in legal pluralism among the Chakma communities perpetuate historical stigma?

Fauzia Sharriff convincingly argues that 'the way the state approaches its relationship with a minority community, not just on the surface but in terms of real commitment, alters in turn how that minority constructs itself (Sharriff, 2008, p. 124). Thus, literature on legal pluralism and stigmatisation highlights the possibility of stigmatising processes leading to a refraction or rejection of attributed stigma - a point that requires analysis of the links between legal pluralism and identity. The remainder of this paper will therefore explore how the strategic use of the law and stigma in response to quite different expressions of state power creates the possibility of Chakma identities that diverge according to their engagements with the state. These engagements are radically different, depending on their location, numerical concentration and the extent to which they were affected by the upheavals visited upon the Chittagong Hill Tracts (CHT) Chakma in the latter part of the twentieth century. But before delving into the different ways in which the Chakma have shaped their stigmatised identities in response to the state, the next section will provide a brief a discussion on the history of the 'tribal' communities in colonial India and post-colonial India and Bangladesh, as well as a short note on how the data for this study were collected.

\section{Context of the study}

The north-eastern borderlands of colonial India are marked by a range of mountains stretching 1,000 miles north to south, from the Western Himalayas to Myanmar. Rising from the plains of Assam and Bengal, the hills were strategically vital, but posed immense challenges to early colonial government due to the hostile climate and topology, and the frequent resistance encountered from hundreds of diverse, self-contained and highly independent communities for whom the mountains were home (Scott, 2009). Their inherent ungovernability initially caused a relatively slow annexation of the hill territories, but fears of further sedition following the 1957 Mutiny affected both the speed and the nature of domination of the hill territories (Mantena, 2010). After this pivotal historical moment, the Zomia were split into new administrative units, or Hill Tracts, which were demarcated by a series of internal borders, or Inner Lines, established apparently without irony to protect both hill dwellers and virgin forests from foreign exploitation (Baruah, 2005; Bhaumik, 2015). Inside the Inner Lines, the British proceeded to enumerate and define each ethnic group according to degrees of backwardness and savagery, whilst attaching to all hill dwellers the inherently stigmatised political category of 'tribe' (Chatterjee, 2011; Skaria, 2001).

Across colonial India, law was instrumental in imposing what was effectively a hierarchy of civilisation, with the near-absolute delineation of the north-east territories forcing the hill peoples to its nadir. The spatial division effected by the Inner Lines was reflected in a bifurcation of legal jurisdiction between urban areas and rural areas, plain-land and hill areas, and citizens and tribes (Mamdani, 2012). State law and state courts had no jurisdiction inside the Inner Lines; instead, government, revenue collection and law were delegated to customary institutions and leaders, who maintained order by enforcing sometimes oppressive traditions against their populations. By colonial design, therefore, identity, law and stigma were inextricably connected in the colonial-era Hill Tracts by the objectified designation of 'tribe'. 
Now divided between Bangladesh and India, the hill regions remain indelibly marked by the legacies of colonial rule - exceptional by dint of their diverse demographic profile, and demarcated from the majority population by constitutional provisions and political strategies that directly or indirectly underscore differential concepts of citizenship for the former tribes. In Bangladesh, the hill peoples of the CHT collectively self-identify as Adivasi, Pahari or Jumma; ${ }^{1}$ they are identified as 'backward' tribes in constitutional clauses promoting their development and are marginalised politically by the strong ethos of Bengali cultural nationalism embedded in the revolutionary republic since independence in 1971. Conversely, post-partition India sustained the protections of the Inner Lines within the Sixth Schedule of the Indian Constitution; recognition as a 'Scheduled Tribe' confers limited legal and political autonomy and the material advantages of valuable quotas in education and employment. Constitutional difference notwithstanding, both nation states are reliant on customary systems to regulate the hill communities, creating a situation of legal pluralism in the former-tribal areas.

To examine how Chakma identities evolved in the post-colonial context, between September 2015 and June 2016, I collected data as part of my doctoral research project in the CHT of Bangladesh and in the Kanchanpur region of Tripura State, India. My project broadly adopted a law-first methodology by focusing inquiries on the already defined customary arena, but mitigated against a possible failure to account for social context by collecting qualitative data from a broad sample of participants and interested parties, and by constructing interviews that initially focused on the social, historical and economic context of customary practice (Cowan, 2004; Mezey, 2001). ${ }^{2}$ In total, eighty-four in-depth interviews with customary and political leaders, activists, lawyers and citizens were conducted in Bangladesh, and eighteen in-depth interviews and five workshops in India. Focus groups were convened on both sites to discuss the role of Chakma law in community life and, where possible, legal hearings were observed and their participants interviewed. Research findings focus on the ways in which community law was deployed as an identity practice and as a form of social regulation. The remainder of this paper will discuss my findings and how legal pluralism in these two post-colonial nations impacts the adoption or rejection of the stigmatised 'tribal' label.

\section{Legal pluralism and stigmatised Chakma identities in Bangladesh and India}

This section explores an inherited triangulation of law, identity and stigma through research in one hill community - the Chakma - as they negotiate the fraught legacy of indirect rule from two geographically and constitutionally distinctive locations: the first in the Rangamati district of the CHT of Bangladesh and the second in the Kanchanpur valley of Tripura State, India. In both sites, the Chakma are minority communities within legally plural systems in which the nature of the state and the nature of their citizenship are hugely influential in the constitution of customary law. The broad hypothesis was that the manifestation of legal pluralism would reflect the way in which each Chakma community used law either to reinforce or reject the historical stigma of the tribe. Answers were sought through a series of interviews with customary leaders and observers, and through observations on the way in which justice is constructed at a village level.

\subsection{The Chakma community of Rangamati, Bangladesh}

In Bangladesh, the Chakma became the first development refugees in South Asia; 40,000 Chakma households, or around 250,000 people, were displaced by the flooding of the Rangamati valley by the Kaptai Hydro-Electric dam in 1960 (Singh, 2010; Chakma and Centre for Sustainable Development, 1995). This cataclysmic event augured a new political consciousness, inspiring

\footnotetext{
'‘Adivasi' is a generic term for autochthone and is used in India and Bangladesh; 'Pahari', meaning hill people, is a common self-designation among the eleven ethnic groups in the CHT; jumma, meaning swidden farmer, is also widely used but has political connotations due to its association with the 'jumma nationalism' of the original JSS political party. The eleven communities are the Bawm, Chak, Chakma, Khumi, Khyang, Lushai, Marma, Mro, Pangkhua, Taunchangya and Tripura (Roy and Gain, 2000).

${ }^{2}$ Cowan (2004); Mezey (2001).
} 
Chakma leader M.N. Larma to invent a wholly novel 'jumma'3 nationalism that melded Marxist-inspired anti-feudalism with the emotional symbolism of the Pahari's common attachment to Jhum agriculture (Van Schendel, 1992). In 1972, jumma nationalism was embodied in the new Chakma-led Jana Samiti Songstad (JSS) political party led by Larma. Its armed cadre, Santi Bahini, ${ }^{4}$ was initially formed to protect the Pahari from postwar incursions into the CHT during the volatile early years of Bangladeshi independence; however, when martial law was again declared in 1975, tensions between the Chakma/Pahari and the state exploded into direct conflict when Santi Bahini launched its first proactive attack on one of the army camps then proliferating in the CHT (Mahmud Ali, 1993). The disproportionately violent state response eventually encompassed murderous attacks on civilians and massive state-sponsored settlements of landless Bengalis on the communal lands of the Chakma and their hill-brethren (Adnan, 2004; Anti-Slavery Society Report, 1984; Levene, 1999). Over the next decade, protection of Bengali settlements justified further militarisation of the region and intensified the Chakma-led insurrection, creating a cycle of violence that dominated the Hill Tracts until the late 1980s (Adnan, 2004).

Conflict dramatically curtailed the use of customary law and customary institutions due to regular forced displacements over the course of the conflict, an Army-enforced ban on cultural gatherings in Pahari villages and the new democratic and avowedly 'anti-feudal' Panchayat structures introduced by Santi Bahini in areas under their control (Ahmed, 1993). When peace negotiations began, however, the still unrepealed CHT Regulation 1900 assumed a critical importance as the legal foundation for recognition of communal land rights. By this stage, the Chakma Chief had been enlisted into peace negotiations but, even so, the invocation of customary law by Santi Bahini was surprising given nearly two decades of decrying the customary system as feudal and outdated. According to former Commander Rupayan Dewan, their leadership felt that customary rights added extra power to their case for political autonomy. ${ }^{5}$ The Peace Accord 1997 (CHTPA) duly referenced the CHT Regulation 1900 as the sole means of solving land disputes and promised consolidation of customary governance under the authority of elected Hill District Councils (HDCs) once these bodies were constituted.

These positive facets of the CHTPA were overshadowed by its weaknesses, however. It had no constitutional weight and was heavily in favour of the state (Roy, 2012). Further, it provided only a barely sketched roadmap towards limited autonomy with no timeframe for implementation and was absent of express commitments either to demilitarise or to address the huge population of Bengali settlers on Chakma land (Chakma, 2012). These criticisms proved prescient; at the time of the research, conflict-related land disputes remained unresolved, the settlement of Pahari land continued unabated and the recommended integration of the customary system into democratic HDCs remained on hold. ${ }^{6}$ More ominously, the CHTPA did not bring peace to the region; rather, it heralded a new and deadly phase of internecine conflict between Parbatya Chattagram Jana Samhati Samiti (United Peoples Party of Chittagong Hill Tracts; Bangladesh) (PCJSS) signatories and anti-CHTPA factions led by the United Peoples Democratic Front, or UPDF (Wilkinson, 2015). Nonetheless, the CHTPA ensured that customary law remained central to political and legal discourse in the CHT. In 2007, the Supreme Court confirmed its primary jurisdiction in Wagachara Tea Estate Ltd v. Muhammad Taher and Others, ${ }^{7}$ the culmination of numerous litigations testing the legal status of the Peace Accord and the continuing relevance of the CHT Regulation. Customary law was also recognised

\footnotetext{
${ }^{3}$ Jumma references the traditional swidden agriculture common to all Pahari.

${ }^{4}$ United Peoples Party. Post 1997, the JSS were renamed the PCJSS or Parbatta Chattagram Jana Samhati Samiti. Their armed cadre, Santi Bahini, means Peace Force.

${ }^{5}$ Rupayan Dewan, CHT Citizens Committee, interviewed 17 March 2016. Rupayan was the Santi Bahini commander responsible for the implementation of the Panchayat system and had also been party to peace negotiations.

${ }^{6}$ According to PCJSS discussants, Bengalis now outnumber indigenous Paharis, meaning that the elected bodies, if constituted, would fall to Bengali control in free elections. The HDCs have been constituted with appointed members, with quotas reflecting the size of each Pahari community. The PCJSS and other Pahari community leaders are resisting elections, whilst the Electoral Commission are insisting that the rights of Bengali settlers should be reflected in the right to vote.

${ }^{7}$ Wagachara Tea Estate Ltd v. Muhammad Taher and Others, Supreme Court of Bangladesh Civil Appeal No. 147 of 2007.
} 
and promoted by the post-conflict United Nations Development Programme (UNDP) development programmes, which channelled resources to the Circle offices for upgrading technology and training customary officials. Thus, through litigation and in the realm of the political, custom remained a source of legitimacy for the Chakma/Pahari in their ongoing struggle to persuade the state to honour their promise of legal and political autonomy to the Chakma and their Pahari brethren.

\subsubsection{Different yet democratically integrated}

Within the Chakma community, views as to the effectiveness of customary law varied, but there was broad agreement the customary legal system was necessary as a bulwark against assimilation with the majority population and to provide legal adjudication to the rural Pahari in light of their widespread distrust of state courts. What emerged from these interviews was a complex picture in which the symbolic importance of the customary system was accompanied by a reforming zeal amongst the Chakma and tacit acceptance of a vibrant internal pluralism. At the village level, there were many choices for adjudications between the customary system, political parties and recourse to local government bodies. This febrile atmosphere framed a common belief that customary institutions had changed significantly since the CHTPA and were capable of absorbing even greater transformations. With only a few exceptions, the customary system was seen as a potentially progressive force within the Pahari community and, for most discussants at least, was a potential source of greater cross-community unity.

The primary advocate for the positive and unifying force of the customary system was its putative head, Raja Devashish Roy, ${ }^{8}$ who cited the evolutionary and socially rooted aspects of the customary system as its major strength. ${ }^{9}$ In terms of legal pluralism, Roy advocated that the customary system be preserved as independent of the formal legal system, expressing a distrust of state institutions that grounded his opposition to the subordination of the customary systems to the HDCs, even if they were democratised. Roy rejected the tribal or backward designation of the states and embraced identification with the international indigenous people's movement. His carefully calibrated negotiation between the necessity for human rights and gender reforms, and historically determined custom demonstrated a clear-sighted view of the Chakma/Pahari as rising above the attribution of tribalism, and the crude dissembling and brutality of both local politicians and the state. The customary system was capable of emic transformation, as evidenced by numerous reforms introduced to address gender inequality in Rangamati. ${ }^{10}$ In terms of pluralism, he opposed the proposed extension of formal family courts into the $\mathrm{CHT}$ and felt it possible to extend customary jurisdiction to Bengalis given the inherent flexibility of customary law. He also opposed integrating customary law with the HDCs, referencing the possibility that they could at some point be dominated by Bengali settlers; this would 'surrender self-determination to an institution over which you have no control'.

All of the seventeen headmen interviewed shared a belief in the customary system beyond its utility in dispute resolution, citing the way it connected the Chakma with their ancestors and traditions in personal and land laws. Customary law, in the words of one headman, 'holds society together', in both a spiritual and a pragmatic sense. Headmen expressly asserted the value of diversity in the customary - that is, the fact that all eleven ethnic groups could practise according to their own traditions. The sense of a society as structured by custom and law was also frequently represented as an inversion of tribal stigma, with customary law seen as the antithesis of unstructured, disordered Bengali society. Half of the headmen interviewed were also PCJSS activists, which perhaps explained their support for a customary system that merged a Chakma normative framework with the ideologies of nationalism and democracy formed through the insurgency and the concepts underpinning the global category of indigenous. Headmen expressed subtle differences with the chief, however, supporting greater formality and closer links with democratic structures as a route to much faster and necessary reform.

\footnotetext{
${ }^{8}$ Raja Devashish Roy is head of the Chakma Circle, an international advocate for indigenous rights and a member of the UN Working Party on indigenous rights.

${ }^{9}$ Raja Devashish Roy, interviewed in February 2016.

${ }^{10}$ Numerous processual women-friendly reforms have been introduced into the customary system by the chief and Rani Yan-Yan.
} 
At the time of the field research, the PCJSS were the most powerful regional political force, with the former insurgent leader Santu Larma ensconced as the appointed - pending elections - leader of the Regional Council. PCJSS discussants explicitly invoked the historical connection between customary laws and land settlement, and expressed their support for the Chakma raj and his customary reforms. ${ }^{11}$ Nonetheless, they distinguished the traditional/customary system in its precolonial form from the 'feudal' system of British invention, arguing that 'the feudal system was not democratic so the feudal system and the traditional system are not the same. ${ }^{12}$ PCJSS discussants were consistent in a desire for democratic control of the customary system, whilst accepting its vital role in maintaining order and preserving unique indigenous cultures. They recognised a legitimate role for the Circle system in sustaining autonomous regulation of social conduct, but highlighted weaknesses that could only be addressed by integrating the customary system into a democratic structure, notably hereditary appointments, gender discrimination and a failure to adhere to human rights doctrines within the system. Formal PCJSS policy, as determined by the CHTPA, is to support the primary jurisdiction of the customary system. In practice, their operatives contributed to a radical pluralism at the village level, with the PCJSS sometimes offering an alternative route to dispute resolution.

\subsubsection{Competing pressures on the Chakma identity: diversification, urbanisation and ideology}

Despite a perceived reduction in case-loads, it appeared that most headmen and Karbari were confident that, in village locations, only a very small number of disputes were taken outside the communitarian arena, where that arena was defined to include local political parties willing to dispense informal justice. That said, each Mauza and village was affected by diverse sets of condition that included demographic factors such as the level of Bengali settlement, physical factors such as proximity to the urban centre of Rangamati, economic factors such as the dominant mode of production and personal factors such as the capacity and inclination of local headmen, Karbari and political activists. These conditions affected local needs for policing and dispute resolution in Pahari areas, and produced highly localised constellations of power and competing systems of local justice from within the communitarian arena. In more urbanised areas, elected members were called upon more regularly to settle local disputes, sometimes with the assistance of customary officials and sometimes without. ${ }^{13}$ In village Mauzas, however, political activists were most likely to affect customary usage through an unauthorised and often unacknowledged usurpation of or interference with the customary system. Practitioners reported that party activists frequently assumed a role in dispute resolution, sometimes in concert with customary officials but sometimes independently. ${ }^{14}$ Recourse to state courts was still infrequent and tended to be viewed as an option only in urban areas. Thus, despite the highly fragmented political and legal environment, the boundaries of the customary system were still meaningful as a barrier across which the state could not intervene but, within that boundary, the communitarian domain exhibited a strong internal plurality through the introduction of political and administrative routes to justice running in parallel with customary adjudications. Further, the communitarian domain was highly malleable and affected by influences well beyond the state.

The expressly anti-peace accord UPDF were a democratic force in the northern regions of the Hill Tracts and Rangamati Circle; their refusal to disarm and frequent resort to sectarian violence have brought the UPDF close to proscription as a terrorist organisation. ${ }^{15}$ They were explicitly Marxist

\footnotetext{
${ }^{11}$ This summary of the attitudes towards customary law was constructed largely from discussions with Ushatan Talukder M.P., Shapti Padhu Tripura, PCJSS Chief Operating Officer, Mangal Kumar Chakma, Chief Press Officer and youth leader Trinijon Chakma. A number of other PCJSS activists were interviewed during the fieldwork.

${ }^{12}$ Mangal Kumar Chakma, interviewed January 2016.

${ }^{13}$ Seeking dispute resolution through elected Upazilla Porishad Chairman is a right transplanted to the CHT from the plain lands.

${ }^{14}$ Some headmen thought the increased presence of alternative systems of justice at a local level affected the number of appellate cases. Three headmen respondents were no longer hearing any cases due to the political problems that they experienced in their Mouzas; indeed, two were unable to return to their villages.

${ }^{15}$ This summary of UPDF policy towards the customary system was drawn from two discussions with Chairman Rabi Sankar Kumar and from a workshop with customary officials from the Sebakkon area.
} 
in ideological stance and more explicitly critical of customary practice than the PCJSS. Chairman Rabi Sankar Kumar saw the accommodation reached between the Chakma Chief and the PCJSS in the CHTPA as a compromise with feudalism. The CHT Regulations, now the source of legitimacy for communal land claims, were 'Protective but ... also representing a lower stage of development. If we had land ownership the Bengalis would not have been able to take our land away' (Interview with Rabi Shankar Chakma, General Secretary of the UPDF, 3 April 2016, Dhaka, Bangladesh). Their decentralised model of local party organisation left considerable flexibility for local activists to decide on appropriate local structures; in UPDF villages, customary structures were frequently bypassed or supplanted by party-political governance and Panchayat arrangements. Nevertheless, they placed local democracy above their ideological position and pragmatically incorporated customary functionaries into their local committee system if the villagers felt it appropriate. As with the PCJSS, their involvement was contingent on the locality, the competency of the customary personnel and local activists' approach to the customary system. According to all UPDF discussants, they prefer not to get involved in customary adjudications and only did so when forced by circumstance.

In terms of ground-level practice, the responses of both political parties suggested a similarly ambiguous and contingent approach to village justice, a disregard for the completeness of the customary system as posited by customary protagonists and a willingness to incorporate or supplant the customary system if requested or required by shortcomings in the local legal constellations at a village level. Despite ideological differences, party justice added to the febrile pluralism in the CHT, whether delivered as separate adjudications or by supplanting the customary system with something akin to a democratic Panchayat system.

\subsubsection{Rejecting stigma in Bangladesh}

Amongst Chakma discussants, legal holism associated with the colonial age had evolved into complex local pluralisms that admitted new concepts of rights, consolidated the political ideal of Pahari solidarity and extended the boundary of customary adjudication to a much wider communitarian sphere. Not only had the stigma associated with the colonial construct of tribe been expressly rejected, but customary law was viewed by its practitioners as exemplars of legal institutions that were more democratic, rights-orientated and adaptable than those provided by the state. They pointed to the increasing participation of women in the system, the women-friendly reforms of the Chakma raj as evidence of a customary system, and greater integrity and accessibility of the customary legal process as opposed to state courts. Customary law was widely valorised as a means of marking the boundaries between community and state, but PCJSS politicians saw nothing sacred in customary adjudications and would intervene in cases in which they had a political interest or where they felt that customary officials were not competent. The UPDF were more hostile to a customary system that they saw as a feudal relic, but absorbed customary officials into local panchayats and observed customary law where democratic considerations demanded it. These multiple perspectives operating within the same customary system generated strong pluralism, being the co-existence of different forms of dispute resolution co-existing and competing. Local customary institutions appeared to provide a forum in which divergent traditional, political and local perspectives could be synthesised and where legal transformation, whether generated by a reforming leadership, internal contestation or through external influence, was perceived as normal and necessary.

\subsection{The Chakma community of Kanchanpur, India}

In India, tribal status under the Sixth Schedule of the Constitution effectively created a new political category of 'tribe' that extended to both autochthonic and immigrant communities such as the Chakma (Beteille, 1986). Claims to tribal recognition have proliferated due to the resource incentives attached to the recognition of culture and the policy of the Indian state to recognise ever more tribes in pursuit of integration and redistributive ends (Kapila, 2008). Despite this, the Sixth Schedule did little to equalise the economic status of the north-east, which remained poorer and less developed than 
plain-land India (Kapila, 2008). Nor did the promise of political autonomy pacify the region, which experienced frequent insurgencies, secessionist movements and civil unrest (Baruah, 2005). It has even been suggested that the constitutional exceptionalism applied to tribal communities exacerbated the historic marginalisation of the hill tribes, whilst undermining the concept of equal citizenship supposedly central to the Indian polity (Chandra, 2013). Even amidst this disorder, however, the Kanchanpur Chakma were unaffected by the surrounding maelstrom of unrest when armed cadres of the Kokborok tribal majority waged a bitter campaign against the mass settlement of Bengali Hindus following Bangladeshi independence (Fernandes, 2011). Instead, the Chakma appeared to remain as the calm eye of a violent storm, achieving constitutional recognition as a Scheduled Tribe in 1976. Ethnic Bengalis form the largest single voting bloc in Tripura due to mass migrations from Bangladesh after the War of Independence in 1971. At the time of research, the number of Chakma members of the State Assembly had been reduced to reflect their decreasing proportion of the Tripura population. Seats on the Tripura Tribal Autonomous District Council (TTADC) are determined by population, as are the number of representatives (MLAs) in the Tripura State Assembly. In tribal politics, the Chakma were the third most populous ethnic group behind the autochthonic Kokborok and Reang tribes - a fact that limits their representation and power on the TTADC. ${ }^{16}$

Tribal recognition confers a limited right to self-government under section 1 of the Sixth Schedule: 'An elected autonomous district council, with legislative and judicial powers, can be constituted under the Sixth Schedule. The council is empowered to make laws on land, water, forest, village or town administration, marriage, divorce and social customs' (Mukul, 1997, p. 928).

Once established, the Autonomous District Council (ADC) can decide whether state legislation applies to their area of administrative control, though the Sixth Schedule provides that recognition of tribal laws must be consistent with the rest of the Indian Constitution. The TTADC convened in 1992 to administer all of the tribal areas of Tripura State, around 68 per cent of its territory, but only, still, about 30 per cent of its population (Bhattacharyya, 2003). Before 1997, discussants reported that Chakma law was practised with minimal hierarchy and formality through the village Karbari, who adjudicated disputes, organised social functions and acted as the local spokesman of the Chakma villagers. Customary reform was instigated to bring the Chakma system into the rural Panchayat system enshrined in the seventy-third amendment of the Constitution and, if absorbed into the formal structures of the TTADC, will secure additional resources for village government. ${ }^{17}$ Chakma law is already formally recognised insofar as cases are referred from the Tripura High Court to the customary system in matters of personal law, but approval of a written Chakma code will empower the High Court to apply customary laws directly.

A new customary structure was duly implemented in 2012 after widespread consultation with the Tripura Chakma. It comprised a four-level hierarchy consisting of courts at village, area, valley and state levels, and closely referenced both the model of Panchayat governance common in rural India and the colonially inspired Circle hierarchy of the CHT. The reconstruction also replaced hereditary appointment to customary positions with a selective system. At the time of the research, the reform programme continued with consultation over a written Chakma Customary Code for submission to the Tripura High Court for formal recognition, meaning that the code would be applied to Chakma litigants in state courts. The new structure was widely perceived as a means of demonstrating the superiority of Chakma customary law to that practised by other tribal communities on the TTADC.

\subsubsection{Adopting the 'tribal' legal identity}

Fieldwork with customary leaders actively prevented interviews with 'outsiders' to the customary system; for example, an invitation to attend the Communist Party of India Marxist (CPIM) Tripura

\footnotetext{
${ }^{16}$ At the time of research, the Chakma held only three of thirty TTADC seats.

${ }^{17}$ This amendment enshrined Panchayat government across all rural areas except those governed by ADC in tribal areas. In tribal areas, customary legal institutions assume the role of panchayats and are subject to the same requirements.
} 
Women's Committee from a prominent Chakma member was withdrawn following intervention from the head of the customary system. In rural areas, it was also clear that the completeness claimed for the customary system by its leaders reflected an empirical reality; the binary of state and customary law held true and the riotous plurality of the communitarian legal field in Bangladesh did not exist in India. Field data from Tripura were therefore slanted more towards the internal practice of customary law and the ways in which recognition under Schedule Six had generated transformation of the customary legal system and had underscored the evolution of Chakma identity.

Amongst the highly literary and culturally aware leadership of the Kanchanpur Chakma, law was part of a rich oral heritage that stretched back to the days in which the Chakma had no government and employed customary laws to regulate the boundaries and behaviour of their community. The first common sphere of consciousness related to the preservation of the unique Chakma legal culture. In sharp contrast to the CHT, Chakma culture and law were tied to that migrant history rather than any concept of land rights or territory. These views were expressed frequently and passionately: 'Even as we migrated to various places our forefathers did not lose our knowledge (the law) creates awareness among the people of the importance of our traditions ... gives unity, and creates a feeling of brotherhood amongst the Chakma' (Interview with Prodip Kumar Chakma, 9 August 2016, Santipur Village, Kanchanpur).

Law was perceived as an essential component of a Chakma identity that referenced a migrant past and created the strong sense of belonging that people need to survive such frequent uprooting. It provided a symbolic cross-border unity between Chakma, but also marked their distinctiveness within the crowded arena of Tripura's tribal politics. Discussions of Chakma identity were frequently couched in themes of the loss and suffering caused by the division of the Chakma nation through migration and conflict: 'The Chakma are mixing with other communities, they are losing their identity, they are losing their culture, so this customary law is very important' (Kinmohan Chakma, Group discussion, 23 July 2016, Gandachara, India). Identity practices were also aligned with a strong sense of marginalisation, forcefully expressed in frustrations at the long delay in Chakma law being recognised as part of the state legal canon. Further, there was no equivalent of jumma nationalism amongst the Kanchanpur Chakma, and no ideology offering a shared vision for minority communities. More than once, smaller Tripura tribes were referred to as dirty and savage by some Chakma participants. Indeed, the newly constructed customary hierarchy was expressly perceived as delineating the Chakma as more developed and more organised than other indigenous groups, which often involved an emphasis on the close proximity of Chakma institutions to the Indian state. Elegant exemplifications of law intertwined the practice of Chakma identity with the role of law in holding chaos at bay - chaos being surrounding political contexts and the disintegration of social structures amongst the young. ${ }^{18}$ Social unity was seen as a vital corollary to this presence, reinforcing the idea of the Chakma as a nation, with one voice. Within the community, however, there was an appreciation of emerging class differentials that increasingly appeared to divide the Chakma into village and town, educated and illiterate, service holder and subsistence farmer. The customary system was perceived as a way of negotiating these schisms, binding the Chakma with cultural and social markers that transcend emerging class/caste division. State recognition of Chakma law was again explicitly connected with the need to assert a strong Chakma presence within the arena of tribal and state politics.

The absolute distinction drawn between customary institutions and the political arena was also noteworthy in its sharp contrast with the CHT. In Tripura, participants uniformly regarded the Panchayat system as entirely independent of formal power in the state - that is, the Tripura State Assembly, where there is only one elected Chakma MLA, and the TTADC, where there are three elected Chakma members. Explicitly party-political positions were not tolerated within the customary system; despite a prevailing discontent with their relative lack of political power, material concerns were not permitted to permeate customary fora. It appeared that the much earlier divorce of the customary sphere from resource allocation - that is, its disaggregation from the allocation of jum land -

\footnotetext{
${ }^{18}$ One Chakma discussant explained how he had addressed illicit drug use and antisocial behaviour in his customary role.
} 
had extinguished the connection between customary law and the regulation of Chakma economic life. This bifurcation of custom from resources played out in the sharp contemporary division of the social/ cultural realm from the political. A belief in the need for customary law to deliver perfect order and the excision of politics from customary institutions characterised the recent promotion of customary law in Kanchanpur. Discourse around resource allocations central to the Chakma as a tribal community never permeated customary institutions; rather, they were conducted in the political arenas of the State Assembly or the Communist Party of Tripura (CPT). Further, the focus on customary law as a cultural artefact appeared to attract largely male and elderly incumbents to the customary hierarchy. Despite the terms of tribal recognition including a minimum of one-third women in customary positions, there were no female personnel with the customary structure; indeed, gender activists apparently chose to focus attention on more inclusive fora such as the CPT. Customary legal regulation had greatest traction in the villages and it was in those more remote locations, amongst the most marginalised of women, that the gender imbalance and the call to order had potentially the greatest effect.

\subsubsection{Emphasising the use of customs}

Amongst the Karbari, there was also a consistent account of a reduction in customary cases, directly attributed to the rise in literacy and the increase in service holders in the area, discussants also linked the fall in cases to the fear of customary justice and the range of punishments that were available to the Karbari in keeping order. The customary system was the means through which social order was maintained - a function that extended beyond the personal to cases of assault, theft and communal disputes, in which cases the customary system supplanted state police in all Chakma transgressions short of murder. Customary officials also played a role in regulating intercommunity disputes, liaising with the officials of neighbouring tribes and only involving the police if their negotiations failed. The preferred model was to negotiate intercommunity disputes without recourse to the state and this additional regulatory role involved at least some tacit of equivalence between the customary systems of neighbouring Tripura tribes, even though many discussants commented that the move to formalise Chakma law was driven by a desire to elevate it above those of minority communities who use highly informal and unrecognised systems of community adjudication. ${ }^{19}$ All of the participants in the research confirmed that family issues formed the largest proportion of cases in Chakma law and land cases were almost all confined to neighbour or boundary disputes. Chakma family law was frequently linked to a need to maintain Chakma bloodlines and to keep land, albeit individually owned, within the Chakma community.

The sharp division between the customary realm and the political was reflected in village adjudications, which were administered solely in terms of Chakma law set out according to the rather conservative Chakma leadership. Achieving order was paramount; for example, in one observed adjudication, the decision of an area Panchayat that censured the corrupt behaviour of a headman was overturned by the Chakma leader for being disruptive of the system. Formal recognition required customary laws to be administered in line with the Constitution, but even these state-driven imperatives had not breached the boundaries of the customary system; aside from the lack of female customary officials in Tripura at the time of research, customary remedies included punishments, like social boycotting, which constituted human rights breaches. Recognition, it appeared, had not generated new conceptions of customary law, but had instead created a customary arena in which the leadership administered justice according to arcane rules with little external challenge.

\subsubsection{Internalising stigma in India}

Observations and interviews suggested that the processes involved in gaining recognition had consolidated and accentuated the very qualities that stigmatised tribal identity in the colonial era and beyond

\footnotetext{
${ }^{19}$ Equivalence in terms of engaging on a community-by-community basis customary duties in Nomen Para, e.g. negotiating if necessary with the Reang who occupied part of the territory. From the Chakma leadership, however, the Reang were often termed a backward or primitive community.
} 
- that is, the over-determination of minorities as differential citizens and law as de-historicised and static. The Panchayat leadership aligned Chakma customary law with an introverted and essentialised nationalism, the ideation of customary law reinforcing the separation of the Chakma from other Tripura tribal groups and transforming their marginalised position into an integral element of cultural identity. Resurgent customary institutions seemed to encapsulate a conservative and patriarchal hierarchy, ossifying the practice of Chakma law and reducing even the possibility of solidarity emerging between the Chakma and other tribal groups.

Returning to the theoretical frame of legal pluralism, the structures created by the Sixth Schedule created a weak pluralism, in that customary and state legal institutions ran in parallel within a statecentred hierarchy. Recognition of customary law required codification, which was seen as a way of strengthening the Chakma vis-à-vis the state and other tribal communities, but would require changes that would integrate Chakma laws further into the state pantheon. There was little evidence of multiple fora for dispute resolution existing in Chakma villages, nor was there evidence of the etic changes to custom required by the Constitution having any effect on the conduct of law. Indeed, customary leadership sought to repel external influences; 'interlegality' was much curtailed by the non-porous borders erected to maintain the idea of perfection in Chakma rural society, to defend against the existential threats to Chakma identity posed by development and to sustain the traditions of the Chakma as passed down over centuries.

Whether these facets of the customary system exacerbated the stigma associated with tribal identity is difficult to say. The Chakma clearly felt marginalised, but more by dominant tribal groups rather than by the majority population, and their relative lack of hegemony had piqued customary reform. There were many hints, however, that outside the villages, customary law had little relevance beyond its social function in organising weddings and other festivals. The resurgence of the customary system was not aligned to political power in Tripura State, but to a more localised political power within the Chakma community. Those who wished for greater influence looked to different arenas to exercise it, suggesting perhaps a residual stigma attached to village life and the inability to escape the clutches of ossified custom. The strong boundaries erected around the customary system sustained it as a cultural identifier but diminished its adaptability and responsiveness. Leadership was dominated by older men, whilst political activists of either gender sought power in the arena of party politics rather than the customary domain.

\section{Conclusion}

The hypothesis presented at the start of this paper was that 'strong' internal pluralism, defined as a proliferation of legal orders, and 'interlegality', defined as admittance of external, even global concepts, are factors more likely to constitute progressive rather than regressive adaptations to customary law in a legally plural environment. The perspectives of law and village practice presented in this paper suggest that this holds true. In Rangamati, the political environment was fragmented, perspectives of customary law differed substantially and there was evidence of competing forms of adjudication arising in village contexts. Yet the customary legal system operated as a forum in which these competing perspectives could be synthesised both at the level of political strategy and in village adjudications. The historical merging of tribal governance under one hierarchy meant the contemporary customary system offered a source of intercommunity unity in a fragmented political environment. Notwithstanding, at a village level, there was evidence that the customary system was no longer the sole means of adjudicating cases and that local dispute-resolution fora drew on customary law and political judgments if circumstances required it. The allegedly 'feudal' structures of colonial-era customary law had evolved into strong pluralism and vibrant interlegality at a local level, and the stigma associated with the colonial construct of tribe had been expressly rejected in favour of a customary system exemplified as being more democratic, rights-orientated and adaptable than those provided by the Bangladeshi state.

In Kanchanpur, the customary system was widely considered entirely discrete from political fora and, though customary officials often occupied other community leadership roles, there was a uniform 
reluctance to engage in any discussion of the wider political or legal context, or to consider that one sphere might influence another. There was a strong emphasis on the importance of customary law to cultural integrity, but also a belief on the part of the customary leadership that a strong Chakma system and a codified body of Chakma law would distinguish the Chakma within the TTADC. As a result, a customary system functioned within a strictly cultural domain, historically divorced from involvement in land and resource transactions, and insulated from wider transformations in society and from the resource-based disputes that characterised the polity in Tripura State and the wider north-east region. There appeared a belief that turning inward towards a reified and rigid Chakma culture assuaged the marginalisation experienced by the Chakma in the crowded tribal polity and the Bengali-dominated State Assembly. Within the boundaries of the system, customary leaders sought perfect order in Chakma society as a bulwark against surrounding disorder, and this was achieved by the imposition of rules from the top of the Chakma hierarchy, the rejection of alternative dispute mechanisms and of external sources of legal knowledge. Tribal stigma was absorbed rather than rejected, with the conceptualisations of law expressed by customary leaders highly redolent of the colonial tropes of a customary domain characterised by insularity and stagnation.

In neither case-study could it be argued that the links between law, identity and stigma had been comprehensively broken when the constitutional framing of state/minority relations in Bangladesh and India still specifically invoked concepts of 'backwardness' that referenced the colonial categorisation of the tribe. However, it is possible to conclude tentatively that the rejection of an explicitly tribal identity appeared closely connected to strong pluralism and interlegality in a post-conflict environment and that, in turn, this was reflected in the transformations visited on the customary legal system in Rangamati. Conversely, the formal absorption of a tribal identity in Kanchanpur and the weak pluralism created through recognition consolidated law as a cultural artefact with little relevance to wider social transformations. Rejection of state hierarchies in Bangladesh was reflected in both resistant identities and transformations in customary law, while acceptance of state hegemony was reflected in a concomitant acceptance of stigma and a fixed and ossified view of customary law.

Acknowledgements. An earlier draft of this paper was presented at the 'Stigmatization, Identities and the Law: Asian and Comparative Perspectives' virtual workshop on 22-25 June 2020, supported by Academic Research Fund Tier II (MOE2018-T2-1-101) and hosted online by the Centre for Asian Legal Studies at the National University of Singapore. I would like to thank especially Dr George Radics of the National University of Singapore for his stalwart advice and support in preparing this paper for publication.

Conflicts of Interest. None

\section{References}

Adnan S (2004) Migration, Land Alienation, and Ethnic Conflict: Causes of Poverty in the Chittagong Hill Tracts of Bangladesh, 1st edn. Dhaka: Research \& Advisory Services.

Ahmed A (1993) Ethnicity and insurgency in the Chittagong Hill Tracts region: a study of the crisis of political integration in Bangladesh. Journal of Commonwealth \& Comparative Politics 31, 32-66.

Anti-Slavery Society Report Number 2 (1984) The Chittagong Hill Tracts, Militarization, Oppression and Hill Tribes, Indigenous Peoples and Development Series. London: Anti-Slavery Society.

Baruah S (2005) Durable Disorder: Understanding the Politics of Northeast India. New Delhi: Oxford University Press.

Beteille A (1986) The concept of tribe with special reference to India. Archive of European Sociology 27, 297-318.

Bhattacharyya H (2003) Indian federalism and tribal self-rule. Federations 3, 11-12.

Bhaumik S (2015) Troubled Periphery: The Crisis of India's North East. New Delhi: SAGE Publications India Pvt Ltd.

Chakma B (2012) Bound to be failed? The 1997 Chittagong Hill tracts peace accord. In Uddin N (ed.), The Politics of Peace. Dhaka: Institute of Culture and Development Research, pp. 121-142.

Chakma H and Centre for Sustainable Development (1995) Bara Parang: The Tale of the Developmental Refugees of the Chittagong Hill Tracts, 1st edn. Dhaka: Centre for Sustainable Development.

Chandra U (2013) Liberalism and its other: the politics of primitivism in colonial and postcolonial India. Law and Society Review 47, 135-168.

Chatterjee P (2011) The curious career of liberalism In India. Modern Intellectual History 8, 687-696.

Cowan D (2004) Legal consciousness; some observations. Modern Law Review 67, 928-958.

Engle Merry S (1988) Legal pluralism. Law and Society Review 22, 869-896. 
Fernandes W (2011) Tribal Commons and Conflicts in Manipur and Tripura in Northeast India Conference Paper, Sustaining Commons: Sustaining Our Future, the Thirteenth Biennial Conference of the International Association for the Study of the Commons, Hyderabad, India, 10-14 January. Available at: https://dlc.dlib.indiana.edu/dlc/handle/10535/7287 (accessed March 2021).

Goffman E (1963) Stigma: Notes on The Management of Spoiled Identity. Englewood Cliffs, NJ: Prentice-Hall.

Griffiths J (1986) What is legal pluralism? Journal of Legal Pluralism and Unofficial Law 18, 1-55.

Guha R (1996) Savaging the civilised: Verrier Elwin and the tribal question in late colonial India. Economic and Political Weekly 31, 2375-2389.

Hunter WW (1876) A Statistical Account of East Bengal VOLUME VI. Chittagong Hill Tracts.. London: Trubner \& Co.

Kapila K (2008) The measure of a tribe: the cultural politics of constitutional reclassification in North India. Journal of the Royal Anthropological Institute 14, 117-134.

Kusow AM (2004) Contesting stigma: on Goffman's assumptions of normative order. Symbolic Interaction 27, $179-197$.

Link B and Phelan J (2001) Conceptualizing stigma. Annual Review of Sociology 27, 363-385.

Levene M (1999) The Chittagong Hill Tracts: a case study in the political economy of creeping genocide. Third World Quarterly 20, 339-369.

Mahmud Ali S (1993) The Fearful State: Power, People, and Internal War in South Asia. London: Zed Books.

Mamdani M (2012) Define and Rule: Native as Political Identity, 1st edn. Cambridge, MA: Harvard University Press.

Mantena K (2010) Alibis of Empire: Henry Maine and the Ends of Liberal Imperialism: Power, Culture, and the Commonplace. Princeton, NJ: Princeton University Press.

Mezey N (2001) Out of the ordinary: power, culture, and the commonplace. Law and Social Enquiry 26, 145-167.

Mukul (1997) Tribal areas transition to self-governance. Economic and Political Weekly 32, 928-929.

Roy D (2012) Challenges towards the implementation of the Chittagong Hill Tracts Accord of 1997. In Uddin N (ed.), The Politics of Peace. Dhaka: Institute of Culture and Development Research, pp. 70-120.

Roy D and Gain P, with the Society for Environment and Human Development (2000) The Chittagong Hill Tracts: Life and Nature at Risk. Dhaka: Environment and Human Development.

Santos B de S (2002) Toward a New Legal Common Sense: Law, Globalization, and Emancipation, 2nd edn. London: Butterworths LexisNexis.

Scott JC (2009) The Art of Not Being Governed: An Anarchist History of Upland Southeast Asia. New Haven, CT: Yale University Press.

Sharriff F (2008) Power relations and legal pluralism: an examination of strategies of struggles amongst the Santal Adivasi of India and Bangladesh. Journal of Legal Pluralism and Unofficial Law 57, 1-43.

Singh DK (2010) Stateless in South Asia: The Chakmas between Bangladesh and India. New Delhi: Sage, New India Foundation.

Skaria A (2001) Hybrid Histories: Forests, Frontiers and Wildness in Western India. New Delhi: Oxford University Press.

Van Schendel W (1992) The invention of the jumma; state formation and ethnicity in south eastern Bangladesh. Modern Asian Studies 26, 95-128.

Wilkinson M (2015) Negotiating with the other: centre-periphery perceptions, peacemaking policies and pervasive conflict in the Chittagong Hill Tracts, Bangladesh. International Review of Social Research 5, 179-190.

Cite this article: O'Brien M (2021). Legal pluralism and stigma: a case-study of customary resurgence in the Chakma communities of Bangladesh and India. International Journal of Law in Context 17, 356-370. https://doi.org/10.1017/ S1744552321000434 